ISSN: 2238-8052

\title{
FRANÇA: MOVIMENTO SOCIAL DOS “COLETES AMARELOS”
}

\author{
FRANCE: "THE YELLOW VESTS" SOCIAL MOVEMENT
}

Beatriz Maria Soares PONTES ${ }^{1}$

Palavras-chave: Movimentos Sociais, Coletes Amarelos, Burguesia Francesa, Violência, Atos Jurídicos.

\section{Keywords:} Social Movements, Yellow Vest, French bourgeoisie, Violence, Legal acts.

\section{R E S U M O}

0 presente estudo tem por objetivo analisar o movimento social dos Coletes Amarelos que, desde novembro de 2018, vem se realizando na França. Os manifestantes reivindicam: a redução nos impostos sobre combustíveis, a reintrodução do imposto sobre fortunas, o aumento do salário mínimo, assim como, políticas de melhoria da democracia representativa, mais precisamente, o Referendo de Iniciativa Cidadã, além do impeachment do Presidente francês, Emmanuel Macron. O Governo francês que é, atualmente, representado pela burguesia do País, com propósitos neoliberais, tem visto, com reserva, as aludidas manifestações e têm uma visão muito negativa dos reivindicantes. Além disso, ocorreram violências quer da parte dos manifestantes, quer da polícia que representa os mantenedores da ordem pública. A jurisprudência francesa, nem sempre tem sido justa, em relação aos Coletes Amarelos. Todavia, levando-se em consideração, não apenas, a situação socioeconômica e política da França, como também, da comunidade global, que apresenta grandes desigualdades sociais, consideramos pertinentes as reivindicações dos manifestantes franceses que, continuam o seu movimento social, até hoje, com a realização das suas lutas todas os finais de semana. 0 movimento social do "Coletes Amarelos" emergiu, significativamente, através das redes sociais (meio tecnológico). As redes, assim como qualquer relação social, estão sempre impregnadas pelo poder, pelo conflito, bem como pelas possibilidades de solidariedade, de reciprocidade e de compartilhamento. Como o movimento ainda está em processo, o principal resultado diz respeito a grande persistência dos trabalhadores franceses nas lutas em favor dos seus direitos humanos e trabalhistas, portanto trata-se de um movimento que apesar de ter recorrido a um meio tecnológico teve a sua evolução e desenvolvimento claramente analisável, através do método dialético.

\section{A B S T RA C T}

The present study aims to analyze the "Yellow Vest" social movement that, since November 2018, has been taking place in France. The protestors demanded: a reduction in fuels taxes, the reintroduction of the tax on fortunes, the increase of the minimum wage, as well as policies to improve representative democracy, more precisely the Citizen Initiative Referendum, in addition to the impeachment of the French President, Emmanuel Macron. The French Government, which is now represented by the bourgeoisie of the country, has for neoliberal purposes, seen, with reserve, the aforementioned manifestations and has a very negative view of the claimants. In addition, violence has taken place both on the part of the protesters and on the part of the police representing the public order. French jurisprudence has not always been fair in relation to the "Yellow Vest". However, taking into account not only the socioeconomic and political situation of France, but also of the global community, which presents great social inequalities, we consider relevant the demands of the French demonstrators who continue their social movement, with the completion of their fights every weekend. The

\footnotetext{
1 Profa. Dra. / Livre-Docente pela UNESP (2008). Profa. Titular aposentada da UFRN. Atualmente, é Professora Colaboradora do Grupo de Pesquisas Movimentos Sociais e Dinâmicas Espaciais (UFPE) e do Grupo de Pesquisas Geopolítica e Território, do Centro de Estudos em Geopolítica e Relações Internacionais (CENEGRI). Presentemente, está envolvida com pesquisas relativas à Geopolítica do Oriente Médio e do Extremo Oriente, com particular ênfase à China. E-mail: lavbiapontes@hotmail.com.
} 
social movement of the "Yellow Vest" emerged, significantly, through the social networks (technological means). Networks, as well as any social relation, are always impregnated by power, conflict, and possibilities for solidarity, reciprocity and sharing. As the movement is still in process, the main result concerns the persistence of French workers in the struggles in favor of their human and labor rights, so it is a movement that despite having resorted to a technological environment had its evolution and clearly analyzable development through the dialectical method.

\section{INTRODUÇÃo}

O movimento social é uma expressão que designa a ação coletiva de setores da sociedade ou organizações sociais para a defesa ou a promoção, no âmbito das relações de classes, de certos objetivos ou interesses - tanto de transformação, como de preservação - da ordem estabelecida na sociedade.

Manuel Castells, refere-se ao movimento social urbano como um sistema de práticas que resulta da articulação de uma conjuntura definida, ao mesmo tempo, pela inserção dos agentes suportes, tanto da estrutura urbana, como da estrutura social, de modo que seu desenvolvimento tende, objetivamente, para a transformação estrutural do sistema urbano ou para uma modificação substancial da correlação de forças na luta de classes, ou seja, em última instância, do poder do Estado. Para o autor, os movimentos sociais urbanos são "sistemas de práticas sociais contraditórias, isto é, que controvertem a ordem estabelecida, a partir das contradições específicas da problemática urbana".

A principal forma que os movimentos têm para conseguir as transformações desejadas é pela discussão de assuntos e organização de manifestações sociais. Isso significa que é através da política que os movimentos sociais lutam pelas causas que defendem.

É comum que os movimentos sociais sejam formados por grupos de pessoas que pertencem a alguma minoria ou maioria social, surgindo a partir da percepção de uma injustiça ou de um problema social.

Também fazem parte dos movimentos sociais, todas as organizações não-governamentais, organizações sindicais, movimentos rurais e movimentos por direitos civis, em geral.

Para que um movimento social exista e, seja organizado, é fundamental que ele tenha uma ideologia, ou seja, que exista uma definição de quais são as causas defendidas e quais são os objetivos a serem alcançados.

Os movimentos sociais podem ser classificados nos seguintes tipos:

- Movimentos de Classe: são os movimentos ligados às diferentes classes sociais e, buscam alguma mudança na ordem social existente, principalmente, em relação à diminuição de desigualdades sociais;

- Movimentos Políticos: têm como principal objetivo, chamar a atenção da população para a importância da participação na vida política e nas decisões do país; 
- Movimentos Reivindicatórios: são os movimentos que buscam soluções para situações mais urgentes e, que usam a pressão contra o Estado, para conseguir as mudanças pretendidas;

- Movimentos Rurais: também são chamados de movimentos do campo e as principais causas são relacionadas à distribuição de terras para a agricultura e a substituição da força de trabalho humana pelas máquinas;

- Organizações Não-Governamentais: são organizações sociais, sem objetivo de lucro, que se organizam por determinadas causas ou para ajudar grupos sociais específicos. Podem atuar em qualquer área como, por exemplo, educação, saúde, assistência social, meio ambiente, entre outras.

Enfim, devemos ressaltar, no período contemporâneo, novas tecnologias, isto é, as redes sociais, que propiciam um maior diálogo e intercâmbio entre as pessoas, das mais variadas áreas de um país ou do mundo, as quais têm tido, no curso dos últimos anos, um enorme significado na construção dos movimentos sociais, entre eles, o movimento social dos "Coletes Amarelos".

Pressupomos, frequentemente, que em uma organização em rede há uma distribuição do poder, que os centros de poder se democratizam, ou, como há muitos centros, o poder se redistribui. Isso é, parcialmente, verdadeiro, porém, mesmo em uma rede há elos mais fortes, mediadores, agentes estratégicos, organizações de referência, entre outros, que detêm maior poder de influência, de direcionamento nas ações, do que outros elos de conexão da rede. Tais elos são, pois, circuitos relevantes para o empoderamento das redes do movimento. As redes, assim como qualquer relação social, estão sempre impregnadas pelo poder, pelo conflito, bem como pelas possibilidades de solidariedade, de reciprocidade e de compartilhamento. Portanto, o que nos interessa é sabermos como se dá o equilíbrio entre essas tendências antagônicas do social e, como possibilitam, ou não, a autonomia dos sujeitos sociais, especialmente, os mais excluídos e que, frequentemente, são as denominadas "populações-alvo" desses mediadores.

As seguintes dimensões sociais merecem estar contempladas para um trabalho de empoderamento democrático e de inclusão social das bases: o combate à exclusão em suas múltiplas faces e a respectiva luta pelos direitos civis e políticos, socioeconômicos, culturais e ambientais; o reconhecimento da diversidade dos sujeitos-sociais e do respectivo pluralismo das ideias, a promoção da democracia nos mecanismos de participação, no interior das organizações e nos comitês da esfera pública, criando novas formas de gestão.

Preparar os sujeitos para se tornarem atores de novas formas de gestão requer a participação em diversos espaços: mobilizações de base local, na esfera pública; empoderamento, através dos Fóruns e Redes da sociedade civil; participação nos conselhos setoriais de parceria entre sociedade civil e Estado e, nos últimos anos, a busca de uma representação ativa, nas conferências nacionais e globais de iniciativa governamental e parcerias com a sociedade civil organizada. 
Nas parcerias entre sociedade civil, Estado e mercado há múltiplas formas de atuação, mas, em termos de participação para a elaboração de políticas públicas, merecem destaque os conselhos e conferências. Nos conselhos setoriais (popular e/ou partidário) é onde há, pelo menos, teoricamente, um espaço institucional para o encaminhamento de propostas da sociedade civil para uma nova governança junto à esfera estatal.

A sociedade civil organizada do novo milênio tende a ser uma sociedade de redes organizacionais, de redes interorganizacionais e de redes de movimentos e de formação de parcerias entre as esferas públicas, privadas e estatais, criando novos espaços de gestão com o crescimento da participação cidadã. Essa é a nova utopia do ativismo: mudanças com engajamento com as causas sociais dos excluídos e discriminados e com a defesa da democracia na diversidade.

Portanto, o movimento dos "Coletes Amarelos" é um movimento de classe, buscando mudanças na ordem social existente, principalmente, em relação à diminuição de desigualdades sociais. Mas, é também, um movimento social político porque solicita que a população participe da vida política e das decisões do país.

Por outro lado, além das características do movimento supracitadas, o maior veículo de entendimento entre os manifestantes foram as redes sociais.

Assim, o objetivo do presente trabalho é analisar o desenvolvimento social dos "Coletes Amarelos", bem como a persistência dos manifestantes, no que concerne às suas reivindicações. No que tange ao método, devemos salientar que foi utilizado o método dialético, focado na questão da formação econômico-social, a qual será, a seguir discutida.

Assim sendo, modo de produção, formação social, espaço - essas três categorias são interdependentes. Todos os processos que, juntos, formam o modo de produção (produção propriamente dita, circulação, distribuição, consumo) são histórica e espacialmente determinados num movimento de conjunto e, isso, através de uma formação social.

A formação social compreenderia uma estrutura produtiva e uma estrutura técnica. Trata-se de uma estrutura técnico-produtiva expressa geograficamente por uma certa distribuição da atividade de produção. Se a noção de formação social, deve conter o complexo das diferentes formas técnicas e, organizacionais do processo produtivo, que correspondem às diversas relações de produção existentes, ela não pode ser concebida sem referência à noção de espaço.

As diferenças entre lugares são o resultado do arranjo espacial dos modos de produção particulares. O valor de cada local depende de níveis qualitativos e quantitativos dos modos de produção e da maneira como eles se combinam. Assim, a organização local da sociedade e do espaço, reproduz a ordem internacional.

Os modos de produção tornam-se concretos sobre uma base territorial historicamente determinada. Deste ponto de vista, as formas espaciais seriam uma linguagem dos modos de produção. 
Daí, na sua determinação geográfica, serem eles seletivos, reforçando dessa maneira a especificidade dos lugares.

A localização dos homens, das atividades e das coisas no espaço, explica-se tanto pelas necessidades externas, aquelas do modo de produção "puro", quanto pelas necessidades internas, representadas essencialmente, pela estrutura de todas as produções e a estrutura das classes, isto é, a formação social propriamente dita.

O modo de produção expressa-se pela luta e, por uma interação entre o novo, que domina e o velho. 0 novo, procura impor-se por toda a parte, porém, sem poder realizar isso completamente. 0 velho, é o modo de produção anterior, mais ou menos, penetrado pelas formas sociais e pelas técnicas que correspondem ao modo de produção novo, mas, sempre comandado pelo modo de produção novo. Daí, chamar-se a esse modo de produção atual, em plena existência, um modo de produção puro: ele não se realiza, completamente, em parte alguma.

Daí, igualmente, a história espacial ser seletiva. Antes do atual período tecnológico, vastos segmentos de espaço puderam escapar ao domínio, direto, ou indireto, do modo de produção dominante, ou foram, apenas, atingidos por feixes de determinações limitadas.

As relações entre espaço e formação social são de outra ordem, pois, elas se fazem num espaço particular e, não, num espaço geral, tal qual para os modos de produção. Os modos de produção escrevem a História no tempo, as formações sociais escrevem no espaço.

Tomada, individualmente, cada forma geográfica é representativa de um modo de produção ou de um de seus momentos. A história dos modos de produção é, também e, sob este aspecto preciso, a história da sucessão das formas criadas a seu serviço. A história da formação social é aquela da superposição de formas criadas pela sucessão de modos de produção, da sua complexidade sobre seu "território espacial", para empregar, ainda que lhe dando um sentido novo, a expressão de que o modo de produção é, uma forma particular de organização do processo de produção destinada a agir sobre a natureza e obter os elementos necessários à satisfação das necessidades da sociedade. Esta sociedade e sua natureza, isto é, a porção da natureza da qual ela extrai sua produção, são indivisíveis e, conjuntamente, chamam-se formação social.

A formação social é, ao mesmo tempo, uma totalidade concreta e uma totalidade abstrata. Seu ponto de vista deve aproximar-se para quem o modo de produção e formação social, devem ser pensados teoricamente, ao mesmo tempo. Assim, o modo de produção é a unidade, a formação econômica e social, a especificidade, mas, ela, sobre bases novas, as especificidades, regra que evitaria julgar o modo de produção como uma essência e como um simples fenômeno.

Não seria, pois, merecida a crítica de não haver fugido, completamente, ao dualismo dos conceitos de modo de produção e de formação social. De fato, a formação social, totalidade abstrata, não se realiza na totalidade concreta, senão, por uma metamorfose, onde o espaço representa o primeiro papel. 
A estrutura do trabalho abrange: a introdução, que se subdivide no assunto relativo ao movimento social dos "Coletes Amarelos" e, a formação econômico-social, como base teórica de análise; França: A burguesia no Poder; 0 Pensamento da Burguesia Francesa sobre a Classe Trabalhadora do seu País; O Movimento Social dos "Coletes Amarelos”; As violências Policial e Jurídica na França, contra os “Coletes Amarelos” e as Considerações Finais.

\section{FRANÇA: A BURGUESIA NO PODER}

Entre o resultado de Macron, no primeiro turno da eleição presidencial, em 07 de maio de 2017 e, o resultado do Movimento La République en March (LRM), no primeiro turno das eleições legislativas, em 11 de junho de 2018, houve uma erosão significativa de cerca de 2 milhões de votos.

Além da aludida mudança de tendência, a abstenção bateu recordes no segundo turno das eleições legislativas: mais de 20 milhões de eleitores, isto é, mais da metade dos inscritos, preferiram, absterem-se. O LRM conseguiu a façanha de obter, com dificuldade, 7.826 .432 votos, 308 cadeiras na Assembleia, ou seja, uma maioria absoluta que permitiu a Macron aprovar seu programa neoliberal.

Em 2017, Macron se cercou, de início, de um primeiro governo de ricos, com 15 de 32 ministros ou secretários de Estado milionários.

Desta forma, a Ministra do Trabalho declarou que o seu patrimônio era de mais de 7,5 milhões de euros; o Ministro da Transição Ecológica e Solidária, apresentou um patrimônio estimado em 7,2 milhões de euros; a Ministra da Cultura, mencionou mais de 600 mil euros, em bens imobiliários e 4 milhões de euros pela empresa de sua propriedade; a Ministra da Saúde, detém um patrimônio, de pouco mais, de 3 milhões de euros; a Ministra do Exército, é proprietária de um patrimônio de mais de 2 milhões de euros, com um apartamento parisiense de $200 \mathrm{~m}^{2}$ e, uma residência secundária, na região de Loiret; a Ministra encarregada das Relações Europeias, declarou um patrimônio de cerca de 1,9 milhão de euros; o Ministro da Economia, declarou partes de uma empresa, avaliadas em 1,5 milhão de euros e, cerca de 168 mil euros em aplicações financeiras; o Porta-Voz do Governo, detinha 1,34 milhão de euros; a Secretária de Estado, encarregada das pessoas com deficiência, era portadora de um patrimônio avaliado em 1,33 milhão de euros; o Secretário de Estado, encarregado das novas tecnologias, era possuidor de patrimônio orçado em 1,26 milhão de euros; a Ministra, junto ao Ministro do Interior, era detentora de 1,27 milhão de euros; a Ministra, encarregada dos Transportes, detinha 1,22 milhão de euros; o Ministro da Coesão dos Territórios, possuía um patrimônio de 1,4 milhão de euros e o Secretário de Estado, junto ao Ministro da Europa e das Relações Exteriores, era detentor de 1 milhão de euros.

Entretanto, o pertencimento de classe não se definia, apenas, pela riqueza econômica. Além dos bens existiam as relações. As mulheres e os homens que, hoje, dispõem do poder político, mesmo 
que distantes da antiga figura dos servidores do Estado, continuam a manter relações estreitas com uma miríade de interesses privados, com os quais eles, frequentemente, têm obrigações a cumprir.

Conselheiros próximos de Macron, também, são oriundos do mundo das empresas e do setor privado. Por exemplo, o Conselheiro sobre as Participações Públicas exercia, antes, um cargo a serviço do grupo aeronáutico Safran; a Conselheira da Cultura começou sua carreira na CAP Gemini e no Boston Consulting Group e a Conselheira de Agricultura trabalhou a serviço de um importante organismo de influência no mundo vinícula, Vin et Société. Entre os 298 colaboradores ministeriais, 43 trabalharam com lobby em algum momento de sua carreira.

Entre funções pública e administração privada, as interconexões desse pessoal tecnocrático são densas, sugerindo que os conflitos de interesses são a regra, ao invés de serem a exceção. Quando se tornam flagrantes demais, pequenos escândalos explodem na imprensa, mas, a árvore oculta a floresta.

Assim, os conflitos de classes repousam no fato referente ao neoliberalismo exacerbado da classe dominante que retém o poder na França, em relação aos reivindicantes, isto é, os "Coletes Amerelos" que se viram altamente prejudicados com as medidas de Macron, alusivas ao projeto econômico do Estado francês.

\section{O PENSAMENTO DA BURGUESIA FRANCESA SOBRE A CLASSE TRABALHADORA DO SEU PAÍS}

Além das múltiplas reivindicações sociais e fiscais dos "Coletes Amarelos", se há uma constante, é sua conviç̧ão de que as "elites" desconhecem suas condições de existência, seu modo de vida e, ainda, os desprezam.

Nas rotatórias das estradas em que os manifestantes se reúnem, nos lembramos, constantemente, das frases com as quais o Presidente francês Macron revelou sua visão do "povo" francês: trabalhadores "analfabetos", destinatários de contribuições sociais, que custam muito dinheiro, "preguiçosos”, "cínicos”, "extremistas”, "pessoas que não são nada” e "basta atravessar a rua para conseguir um emprego".

A grande pergunta é "o que é o povo?" O Presidente responde: "São aqueles que se devem educar, até mesmo reeducar, aqueles que são refratários, que se devem guiar, aqueles que se queixam, em vez de tomarem conta de si mesmos e, assumirem responsabilidade e aqueles que, com muita frequência, não são nada".

Sem dúvida, o Presidente francês expressou de forma significativa, a filosofia social do mundo ao qual pertence, do mundo em que ele se formou, uma filosofia social, geralmente, eufemizada ou reservada aos círculos de seus pares.

Portanto, os executivos que falam demais, conforme a opinião de um trabalhador, têm todo o interesse em alimentar essa visão uniforme e negativa dos operários, como grupo social, evitando o 
transtorno que poderia resultar de um entendimento mais realista. Qualquer desejo de entender iria minar sua crença na legitimidade de sua participação ativa nas reestruturações industriais. 0 desprezo e o mal-entendido condicionam, assim, a cegueira socialmente necessária à sua missão. E, é essa filosofia do desprezo que os "Coletes Amarelos" recusam.

A cristalização de um ressentimento como o atual contra o Presidente Macron, resulta em parte, da fraqueza de seu capital político. Ele foi eleito graças a uma combinação de circunstâncias: dois presidenciáveis, François Hollande e François Fillon, sem condições de vencer; uma Frente Nacional, no segundo turno, que obrigou muita gente a votar em Macron, por falta de opção; uma abstenção maciça de pessoas, no primeiro turno das eleições presidenciais e 24,5 milhões, no primeiro turno das eleições legislativas mostrou que o Presidente é um político sem traquejo político que chegou ao poder.

Lograr traquejo político é, pelo menos, tentar "enquadrar" com uma retórica, relativamente, eficaz as humilhações sociais que são impostas, além de fingir simpatizar com o sofrimento dos mais pobres, com as dificuldades com que muitos têm de lidar. É prometer colocar um fim na fratura social, como o fez Jacques Chirac, em seu tempo, ou abraçar o ponto de vista daqueles que só podem contar consigo mesmos - tão numerosos nas classes populares que, muitas vezes, essa infelicidade é encarada como um ponto de honra -, como comprometendo-se a apoiar seus esforços, à maneira de Nicolás Sarkozy, que isentou de impostos as horas extras e não parava de tecer considerações positivas àqueles que se levantavam cedo.

Essa falta de traquejo político caracterizou muitos deputados do partido no poder, A República em Marcha (LRM). Assim, dos 521 candidatos do LRM, nas eleições legislativas de 2017, 281 nunca haviam exercido um mandato. Assim, todo o recurso de que dispunham em um capital social, que pouco os predispunha a compreender os "Coletes Amarelos", pelo fato dos referidos deputados pertencerem as categorias socioprofissionais mais elevadas e os empresários que exerciam atividades de consultoria. As discussões dos "Coletes Amarelos" testemunham a sua forte percepção desse necrotério social. Como a burguesia francesa não têm a menor ideia do valor do salário mínimo, daí resultou que a alegação de que não se poderia morar em um universo extraordinário, com gramado, montanhas, vista excepcional, com um hospital ao lado, uma farmácia próxima, as pessoas não tinham como questionar ou reclamar. Assim sendo, sem traquejo, seria exatamente dizerem o que pensam, isto é, a burguesia francesa.

De classes perigosas a multidões furiosas, de maus pobres a escória, de desclassificados a marginais, a concentração de desprezo pelas classes populares tem uma longa história. Assim sendo, a burguesia os proíbe, em particular, de entender as racionalidades que são a base do estilo de vida popular. Foi, aliás, a insensibilidade, em relação ao lugar ocupado por eles, no cotidiano, de porções inteiras das classes populares, que foi sancionada pela explosão do movimento dos "Coletes Amarelos", que tais fatos tornaram-se muito claros. Multiplicação de radares, velocidade limitada a $80 \mathrm{~km} / \mathrm{h}$, 
aumento no preço da gasolina, imposto chamado de "ecológico" sobre os combustíveis, controle técnico mais caro e mais rigoroso, restrições ao diesel: ao reduzir a liberdade de deslocamento, foi toda uma economia material, de lazer e de sociabilidade, especialmente, nos chamados mundos rurais, que o poder inconscientemente perturbou. Tomadas por um Presidente arrogante e interpretadas por aqueles que foram afetados como uma negação adicional de seu ser social, essas medidas dirigidas ao automóvel, liberaram uma raiva, até então, contida, ou não muito visível, que se atualizou e cristalizou na rejeição, na exigência de renúncia de Macron.

\section{O MOVIMENTO SOCIAL DOS “COLETES AMARELOS”}

O movimento dos "Coletes Amarelos" é um movimento social de protesto espontâneo, que começou com manifestações na França, em novembro de 2018 e, posteriormente, se espalhou para outros países. Inconformados com o aumento dos preços dos combustíveis e pelo alto custo de vida, com a consequente redução do poder de compra, assim como, pela afirmação de que as reformas fiscais e sociais propostas pelo Governo do Presidente francês Macron impactariam, diretamente, as classes trabalhadoras e médias, especialmente, nas zonas rurais e áreas periurbanas. Manifestantes estavam pedindo reduções nos impostos sobre combustíveis, a reintrodução do imposto sobre fortunas, o aumento do salário mínimo, assim como, políticas de melhoria da democracia representativa, mais precisamente, o Referendo de Iniciativa Cidadã, além do impeachment do Presidente francês Emmanuel Macron.

O Movimento tem sido muito visível nas cidades francesas, mas também, apresenta uma presença maior que o habitual, nas regiões rurais. Obrigatório por Lei, em todos os veículos da França, o colete amarelo se transformou num símbolo do protesto, pela ampla disponibilidade, baixo custo e simbolismo.

Ao analisarmos a revolução dos preços nas bombas de combustíveis desde 1990, observamos que o preço no fim de 2017, se situava na média de preços de 1960. Contudo, a situação real, era totalmente diferente, ao levarmos em conta o fator de alastramento urbano, que incitou, cada vez mais, os moradores de zonas periurbanas a usarem seus carros para se deslocarem a distâncias maiores, com a finalidade de chegarem aos seus trabalhos, nos centros urbanos.

Foi, então, que o Governo decidiu incluir uma taxa sobre a emissão de carbono no imposto interior de consumo sobre os produtos energéticos, o preço na bomba de combustível aumentou cerca de $23 \%$ para o gás e 15\% para a gasolina, de outubro de 2017 a outubro de 2018. A França, portanto, passou a se situar um pouco acima da média da União Europeia (UE) que é a região com a maior taxação sobre os combustíveis fósseis.

Os impostos cobrados sobre a venda de combustíveis são: 
- 0 consumo interno de imposto sobre os produtos energéticos (TICPE). Este imposto não é calculado com base no preço do petróleo, mas, por uma taxa fixa por volume. Parte deste imposto, pago na bomba de gasolina, vai para os governos regionais, parte vai para o governo nacional. Desde 2014, este imposto tem incluído um componente de carbono, acrescido a cada ano, com o objetivo de reduzir o consumo de combustíveis fósseis. 0 aludido imposto (TICPE) para combustível diesel foi aumentado, mais radicalmente, em 2017 e 2018, para trazer os mesmos níveis, como o imposto sobre a gasolina;

- O Imposto sobre o Valor Acrescentado (IVA), calculado com base na soma do preço sem imposto e o montante do imposto sobre o inicialmente salientado (TICPE). A taxa tem se mantido instável em 20\%, a partir de 2014, depois de ter sido de 19,6\%, entre 2000 e 2014

Este Movimento de protesto contra os preços dos combustíveis, como por exemplo, aquele referente a profissões e atividades de benefícios parcial ou total de isenção do TICPE.

Os manifestantes criticaram o governo pela repercussão sobre o consumo final e pela alta dos tributos decorrentes da emissão do carbono. Como o imposto sobre o carbono tem sido, progressivamente, aumentado para satisfazer objetivos ecológicos, muitos dos que escolheram o fóssil - combustível de aquecimento para suas casas fora dos centros urbanos, onde um carro é necessário está descontente.

O Presidente Macron tentou, então, dissipar estas preocupações, no início de novembro de 2018, mediante a oferta especial de subsídios e incentivos.

Por exemplo, o diesel na França, teve os preços aumentados em cerca de 16\%, em 2018, com impostos em ambos, isto é, a gasolina e o diesel, aumentando, ao mesmo tempo, além de mais um aumento de impostos previsto em 2019, portanto, os aumentos em relação ao diesel foram maiores dos que os referentes à gasolina.

Em 29 de maio de 2018, uma moradora de Seine-et-Marne, iniciou uma petição no site change.org, atingindo 300 mil assinaturas, até meados de outubro. Dois meses depois, a referida moradora, já havia logrado cerca de 1 milhão de assinaturas. Paralelamente, dois homens da mesma cidade, lançaram um evento no Facebook, para o dia 17 de novembro, com o intuito de bloquear todas as estradas, com a finalidade de protestar contra um aumento dos preços dos combustíveis, que eles consideravam excessivos, afirmando que este aumento foi devido ao aumento dos impostos. Um dos vídeos em torno deste grupo, lançou a ideia de usar casacos amarelos. A partir desta ideia dos casacos amarelos surgiu outra ideia, qual seja, dos coletes amarelos.

O movimento dos "Coletes Amarelos" não está associado a um determinado partido político ou sindicato. Teve grande repercussão devido aos meios de comunicação e as redes sociais. 
Assim, começamos a acompanhar o movimento dos "Coletes Amarelos", abrangendo 20 fins de semana consecutivos, dos protestos que se realizaram em Paris, além de outras cidades francesas, a partir de novembro de 2018.

Devemos salientar que, optamos por abranger a nossa reflexão sobre os 20 fins de semana, já consumados, tendo em vista que o movimento social em tela, ainda prossegue e, não sabemos, quando é que o mesmo será encerrado.

Na verdade, foi uma medida que assumimos para estabelecer os limites temporais do nosso trabalho, pelo fato do mesmo, refletir sobre um movimento social que, no âmbito da história contemporânea, ainda está em andamento.

Examinaremos, a seguir, os principais acontecimentos verificados em cada um dos fins de semana, já estabelecidos, neste trabalho.

- 1므 Semana: de 17 a 23 de novembro de 2018. No dia 17 de novembro de 2018, tiveram início os protestos que mobilizaram mais de 300 mil pessoas, em toda a França, com barricadas e bloqueio de estradas. De acordo com um jornalista que testemunhou as rebeliões, as manifestações não foram um protesto, mas, uma insurreição. Além de estradas, os manifestantes, também, bloquearam cerca de 10 depósitos de combustíveis. Neste primeiro dia de protestos, uma pensionista de 63 anos, foi atropelada por um motorista em Le Pont-de-Beauvoisin, enquanto se manifestava, na rotunda que dava acesso a uma zona comercial. Um motociclista morreu depois de ser atingido, no mesmo dia, por uma van, tentando contornar uma barricada. Até 21 de novembro, 585 civis tinham sido feridos, sendo que 16, gravemente e, 115 policiais, dos quais 3, seriamente feridos, também. Os protestos também ocorreram na região ultramarina francesa de Reunião, onde a situação se deteriorou em saques e tumultos. As escolas da ilha foram fechadas por 3 dias, após as manifestações terem bloqueado o acesso às estradas. No dia 21 de novembro, o Presidente Macron, ordenou o envio de tropas para a ilha, visando acalmar a violência.

- $2^{\text {a }}$ Semana: de 24 a 30 de novembro de 2018. No dia 24 de novembro, aumentaram as tensões em Paris e, para tentar estabelecer um armistício, o Ministro do Interior concordou em permitir um encontro no Champ de Mars, em 24 de novembro. Neste mesmo dia, os protestos atraíram 106 mil pessoas em toda a França, conforme o Ministério do Interior, das quais apenas 8 mil estavam em Paris, onde os protestos se tornaram, ainda, mais violentos. Os manifestantes ascenderam fogueiras nas ruas, derrubaram placas, construíram barricadas e arrancaram paralelepípedos. A polícia recorreu a gás lacrimogêneo e canhões de água, a fim de dispersar os manifestantes. 
- 3a Semana: de 01 a 7 de dezembro de 2018. No dia 01 de dezembro, foi organizado um protesto chamado Ato 3 - Macron - Demissão. 0 tráfego na rodovia que liga Marselha à Paris parou ao norte de Lyon, durante parte do fim de semana de 01 a 02 de dezembro. Em Marselha, onde manifestações vinham sendo frequentes, desde 05 de novembro, quando um prédio desmoronou e suas redondezas foram evacuadas, uma mulher argelina de 80 anos, tentou fechar a veneziana de sua janela, quando foi atingida por estilhaços de uma lata de gás lacrimogêneo, morrendo depois, durante uma cirurgia. Um segundo motorista morreu, no terceiro fim de semana, depois de espatifar a sua van, em caminhões parados em uma barricada na Passagem de Arles.

- 4a Semana: de 08 a 14 de dezembro de 2018. Durante as manifestações de sábado, 08 de dezembro, o Ministério do Interior informou que ocorreram, ao todo, 1.723 detenções (1.082, somente em Paris). Destes, 1.220 manifestantes foram presos preventivamente. Segundo o órgão, cerca de 136 mil pessoas foram às ruas, em todo o país. Na capital francesa, o número de manifestantes foi o mesmo do sábado anterior, isto é, 10 mil pessoas. 0 prejuízo causado pelo vandalismo foi maior do que o observado na semana anterior, embora os meios de comunicação tenham noticiado um clima mais calmo. Carros e estabelecimentos comerciais foram depredados, constituindo-se em uma catástrofe para as lojas e estabelecimentos comerciais, que foram depredados. Ocorreram nesta semana grandes preocupações com as instituições, após as semanas de protesto. Um total de 264 pessoas foram feridas, alguns seriamente, com a perda de olhos e de mãos, mais precisamente, em razão da utilização de armas de uso não-letal e bombas de efeito moral, pelas forças policiais. No dia 14 de dezembro, o Presidente Macron, fez uma alocução televisiva, na qual anunciou diversas medidas destinadas a colocar fim ao conflito. 0 discurso, porém, não convenceu a maior parte dos manifestantes e eles mantiveram os bloqueios nas estradas.

- 5a Semana: de 15 a 21 de dezembro de 2018. Segundo o Ministério do Interior, o número de manifestantes, no sábado de 15 de dezembro, foi menor que o precedente (4 mil em Paris e 66 mil, em todo o território francês). Cerca de 69 mil membros das Forças da Ordem foram destacados sobre todo o território (uma razão de 1 membro da Força da Ordem para cada manifestante), 8 mil somente em Paris, onde 179 pessoas foram detidas e, destas, 144 foram colocadas em prisão preventiva. Os meios de comunicação, noticiaram que a situação ainda estava tensa em Bordeaux, Nantes e Toulouse.

- 6a Semana: de 22 a 28 de dezembro de 2018. Os "Coletes Amarelos" mais determinados, insatisfeitos com as concessões do Governo, começaram a protestar na França, neste sábado 
(22), pela $6^{\mathrm{a}}$ semana consecutiva, mas, a mobilização perdeu força. Uma das manifestações foi convocada para o Castelo de Versalhes, que fica a cerca de $20 \mathrm{~km}$ a sudoeste de Paris e recebe milhões de turistas a cada ano. Como precaução, o prefeito do Departamento de Yvelines, ordenou o fechamento do local. Todavia, durante a manhã de sábado eram observados, apenas, os caminhões das Forças de Segurança. "Espero que não sejamos afetados por este novo dia de protestos. Nós trabalhamos, não podemos parar de viver", criticou um açougueiro, referindo-se aos atos de vandalismo contra estabelecimentos comerciais de Paris, ocorridos nos sábados anteriores. Uma das reivindicações dos manifestantes foi o Referendo de Iniciativa Cidadã, que o Governo prometeu estudar. A $10^{\underline{a}}$ vítima fatal foi registrada nesta semana, quando um motorista bateu em um caminhão que estava parado em um ponto de bloqueio, em uma rodovia perto de Perpignan, no sul do país. O Presidente francês, Macron, anunciou uma série de medidas para reduzir a crise dos "Coletes Amarelos", algumas delas aprovadas pelo Parlamento. Entre as medidas, estava o fim de um novo imposto para os aposentados que recebem pequenas pensões, a isenção de impostos e contribuições sociais às horas extras e a possibilidade de um "bônus excepcional" de 1.000 euros, livre de impostos para os trabalhadores que ganham menos de 3.600 euros.

- 7a Semana: de 29 de dezembro de 2018 a 04 de janeiro de 2019. Pelo menos, 57 pessoas foram presas pelos protestos referentes ao movimento dos "Coletes Amarelos". A Diretoria de Segurança da França informou que cerca de 800 pessoas participaram de manifestações na capital, Paris e, 12 mil pessoas participaram dos protestos em todo o país. Uma parte dos manifestantes foi agrupada na Avenida dos Campos Elíseos, em Paris e, outras centenas se encontraram em frente aos edifícios de algumas instituições da mídia. A polícia interveio com spray de pimenta contra os manifestantes, próximo ao centro comercial de Beaugrenell. Os manifestantes na Praça de Trocadéro lançaram slogans de "Renúncia de Macron". Alguns manifestantes atearam fogo a lixeiras e incendiaram o prédio do Banco Central. Na manifestação organizada em Bordeaux, com a participação de 2.400 pessoas, a polícia respondeu com spray de pimenta sobre os manifestantes que atiraram pedras e garrafas na força policial. Nas manifestações em Nantes, uma pessoa ficou gravemente ferida. A mobilização dos "Coletes Amarelos" que começaram em 17 de novembro, para protestar contra o aumento dos custos de combustível e o agravamento das condições econômicas, transformou-se em ódio e rebelião contra o Governo Macron, entrando para a História, como o protesto mais violento no país, no curso dos últimos anos.

- 8a Semana: de 05 a 11 de janeiro de 2019. Apesar do Governo francês ter proibido manifestações, no presente sábado, os "Coletes Amarelos" voltaram às ruas das cidades 
francesas, incluindo, a Avenida dos Campos Elíseos, em Paris. Com esta 8 ${ }^{\underline{a}}$ semana de protestos, o movimento dos "Coletes Amarelos" continuou desafiando as medidas do Governo. As autoridades, por sua vez, consideraram uma insurreição, reclamando a necessidade da vigência da ordem pública. Menos numerosas, no começo do dia, mas, ao final do mesmo, com um número de 50 mil pessoas, as manifestações do movimento dos "Coletes Amarelos" continuaram em várias cidades da França, inclusive, em Paris, na famosa Av. dos Campos Elíseos, pelo 8o sábado consecutivo. Os "Coletes Amarelos" continuaram a desafiar, nas ruas, as autoridades francesas, as quais proibiram as manifestações para este sábado, denunciando arbitrariedades na insurreição dos manifestantes radicais, com a sua pretensão de impor desordem pública no país. Todavia, muito determinados, mais de 1.000 (mil) "Coletes Amarelos", andavam, esta manhã, na calma, por várias ruas de Paris, tendo partido do Arco do Triunfo, nos Campos Elíseos, reclamando um Referendo de Iniciativa Cidadã, mais poder de compra e a demissão do Presidente Macron. "Estaremos nas ruas até que Macron satisfaça as nossas reinvindicações, porque na metade do mês, já não temos recursos na carteira", clamava uma manifestante, enquanto uma outra dizia não acreditar "nas medidas anunciadas pelo Governo". Mas, este clima de denúncias feitas na calma, foi quebrado à tarde com os primeiros confrontos entre manifestantes e as Forças da Ordem. Às margens do Rio Sena, junto à Câmara Municipal de Paris, manifestantes apedrejaram Forças da Polícia que replicaram, lançando canhões de água e gás lacrimogêneo, para dispersar a manifestação. As Forças da Ordem receberam reforços de forças da Polícia de Segurança Militar, para controlar os manifestantes mais radicais. Entretanto, houve também, manifestações em Toulouse, Bordeaux e Lyon, onde milhares de "Coletes Amarelos" bloquearam, nos dois sentidos, a autoestrada A7, que atravessa esta terceira cidade francesa do centro-leste, provocando congestionamentos e bloqueios na circulação. Protestaram, igualmente, em frente à Câmara Municipal da cidade, de cujas imediações foram expulsos pelas forças policiais. Estamos, pois, no fim da tarde, perante mais um sábado de violência, como tem acontecido há 8 semanas, nas principais cidades da França. Houve, inclusive, cenas de violência em várias cidades do Oeste da França, como Rouen e Nantes, onde uma pessoa ficou ferida, enquanto em Rennes, cerca de 2.000 manifestantes e, entre eles, um grupo partiu uma porta de vidro da Câmara Municipal. Os "Coletes Amarelos" utilizaram, uma vez mais, a tática urbana de ocupar vários lugares dispersos pelas cidades, começando as manifestações na calma, durante a manhã, para terminarem com atos de violência, no final da tarde, já próximo à noite que caía. Uma tática de violência que culminaria com um grupo radical dos manifestantes, atacando as instalações ministeriais do Secretário de Estado e Porta-Voz do Governo, evacuado ileso pela sua segurança. 0 grupo de indivíduos violentos que sabia que o Porta-Voz do Governo estava no seu gabinete atacou com uma viatura escavadora, danificando a porta principal do edifício 
em Paris. O Porta-Voz denunciou, um "ataque à democracia e à República", condenando os atos de violência, durante as manifestações deste dia que reuniram mais de 50 mil pessoas.

- 9a Semana: de 12 a 18 de janeiro de 2019. 0 Governo da França mobilizou 80 mil agentes de segurança para a manifestação deste sábado e, o Ministro do Interior, ameaçou retaliações duras contra a violência. Na capital francesa, as tensões aumentaram entre os manifestantes e a polícia, no final da marcha, próximo ao monumento do Arco do Triunfo. As Forças de Segurança usaram gás lacrimogêneo e canhões de água para dispersar um grupo que jogava pedras e outros objetos. A polícia de Paris informou que, pelo menos, 53 pessoas foram presas antes e, durante o protesto, em Paris. 0 movimento dos "Coletes Amarelos" minguou durante os feriados de fim de ano, mas, voltou a ganhar força, apesar das concessões de Macron. Os manifestantes desejam mudanças econômicas e políticas mais profundas na França.

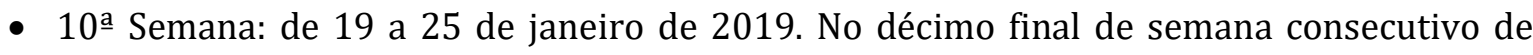
protestos, cerca de 84 mil manifestantes do movimento dos "Coletes Amarelos" saíram às ruas, na França, para protestar contra o Governo de Macron, neste sábado (19). A passeata dos manifestantes por Paris, onde se estimou a participação de 7 mil pessoas, foi relativamente pacífica, apesar de conflitos no Distrito de Invalides entre a polícia e um grupo de manifestantes. Estes, jogaram bombinhas, garrafas e pedras nos policiais, que responderam com canhões de água e gás lacrimogêneo. 0 número de participantes da manifestação deste sábado, foi parecido com o da semana anterior. A taxa prevista sobre os combustíveis foi revogada, mas, mesmo assim, os protestos continuaram transformando-se em um movimento mais amplo contra Macron e o custo de vida na França. "Como podemos continuar a viver com tão pouco?", perguntou uma pessoa que protestava, aposentado de 65 anos, que participou dos protestos de Paris. Lá, alguns manifestantes carregaram caixões falsos que simbolizavam as dez pessoas que morreram durante os protestos, principalmente, em acidentes de carros - o bloqueio de vias é uma prática corrente do movimento. Os protestos de dezembro trouxeram algumas das cenas mais violentas das últimas décadas, em Paris, como a queima de carros e vandalismo em lojas. Segundo números oficiais, o maior protesto deste sábado foi na cidade de Toulouse, no sul da França, onde participaram mais de 10 mil pessoas. A manifestação ganhou contornos violentos no começo da noite, com vandalismo de bancos e outros estabelecimentos. Oito pessoas se machucaram e 23 foram detidas. 
- 11a Semana: de 26 de janeiro a 01 de fevereiro de 2019. Dezenas de milhares de pessoas marcharam pelas ruas da França, no 11ำ dia de protestos contra o Governo Macron e, suas medidas econômicas antipovo, no que ficou conhecido como o protesto dos "Coletes Amarelos". Os protestos ocorreram em todo o país, pelo 11ำ final de semana seguido, englobando as cidades de Paris, Toulouse, Montpellier, Bordeaux, Marselha, Dijon, Lyon, Valence e Nantes, dentre outras. Segundo o Ministério do Interior, o número de manifestantes foi superior a 60 mil pessoas. Apesar do alto número reconhecido pelo Governo, há uma grande suspeita de que estes sejam números subestimados. Há, hoje, em toda a Europa, um fenômeno que os manifestantes chamam de "bloqueio midiático", porque a cobertura do monopólio de imprensa e os números divulgados pelas "autoridades", buscam reduzir a vitalidade dos protestos, visando esvaziá-los. A massa de manifestantes, mais uma vez, pediu a renúncia de Macron - exigência que prossegue desde novembro de 2018 -, quando iniciaram-se os protestos. A repressão, novamente, se impôs de forma contundente contra os protestos. Pelo menos, 223 (duzentos e vinte e três) jovens e trabalhadores foram detidos, alguns deles por responderem com justa violência à repressão iniciada pela polícia que queria acabar com os protestos, a mando do Governo. Em Paris, próximo à Praça da Bastilha, uma trabalhadora - uma ativista pacifista - foi gravemente ferida no olho, após ser atacada por policiais franceses. Além da repressão oficial, um grupo fascista de extrema-direita, autodenominado ZOUAVES - formado por ex-militantes do grêmio estudantil de extremadireita GUD - atacou, violentamente, um bloco de ativistas do autodenominado Novo Partido Anticapitalista, uma organização trotskista francesa. Duas pessoas foram feridas pelos fascistas. Em Montpellier, sul da França, um policial foi ferido pelos manifestantes com uma bomba incendiária caseira, em resposta à violenta repressão, iniciada pelos agentes. Já em Bordeaux, sudoeste do país, grupos de jovens combatentes prosseguiram com os protestos, durante a madrugada, resistindo à repressão policial com fogos de artifício e bombas incendiárias.

- 12 - Semana: de 02 a 08 de fevereiro de 2019. Os "Coletes Amarelos" tomaram, novamente, as ruas da França neste sábado (02), para manter a jornada de pressão sobre o Governo do

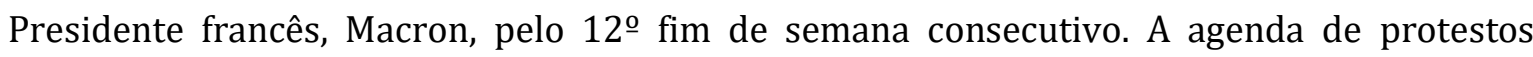
convocou manifestação em Paris e, em outras cidades, para denunciar as políticas econômicas de Macron, de redução de direitos sociais e de crescimento da pobreza. Nesta semana, manifestantes na capital francesa, planejaram prestar homenagem aos "Coletes Amarelos" feridos, durante os confrontos com a polícia. 0 Governo disse que, cerca de duas mil pessoas ficaram feridas em protestos, desde o início do movimento, incluindo, pelo menos, 4 lesões oculares graves. Cerca de 10 pessoas morreram em incidentes rodoviários ligados aos 
protestos. O Conselho de Estado da França, decidiu, nesta sexta-feira, que as Forças de Segurança têm o direito de usar controversos lançadores de balas de borracha de alta velocidade para o controle de multidões.

- 13a Semana: de 09 a 15 de fevereiro de 2019. Os "Coletes Amarelos" retomaram, em toda a França, os protestos contra o Governo de Macron, neste sábado (09). Esta é a 13a manifestação, desde o início do movimento, agora, enfraquecido depois de 3 meses nas ruas. Um manifestante perdeu a mão, durante confronto em Paris, segundo a imprensa. Na capital francesa, os "Coletes Amarelos" se reuniram pela manhã, em torno do Arco do Triunfo. Centenas de pessoas seguiram em caminhada até a Torre Eiffel. Houve um confronto com as Forças de Segurança, próximo à Assembleia Nacional e, um manifestante perdeu a mão ao tentar segurar uma bomba de gás lacrimogêneo, com a intenção de joga-la contra os policiais, segundo a emissora BFM TV. Ele, também, ficou ferido no rosto e foi levado pelos bombeiros para um hospital. No restante da França, houve manifestações previstas em Lille, Nantes, Rennes, Brest, Bordeaux e Toulouse, palco de confrontos nas últimas semanas. A mobilização dos "Coletes Amarelos" começou em protesto contra um imposto sobre o combustível para desestimular a utilização de transporte individual. Embora, o Governo tenha voltado atrás na cobrança, a pauta de reivindicações se ampliou motivada pela queda no poder aquisitivo, pela pressão fiscal e pela busca por reformar para construir instituições mais representativas. 0 Movimento tem representantes de várias correntes políticas que vão, desde simpatizantes da extrema esquerda, até a extrema direita. A pesquisa do "YouGov", publicada na quinta-feira, indicou que dois, em cada três franceses (64\%) apoiam o Movimento, segundo a France Press. Porém, nos últimos dois sábados, a mobilização foi menor. Segundo o Ministério Francês do Interior, 58.600 pessoas se reuniram, em 02 de fevereiro. 0 Movimento rejeita esse número e fala em 116 mil manifestantes. Na primeira manifestação, 287.710 pessoas participaram. O Movimento está provocando um importante conflito diplomático entre a França e a Itália, depois que o líder do Movimento 5 Estrelas e, o número dois do Governo italiano, terem se reunido com um dos líderes dos "Coletes Amarelos". Na quinta (7), o Governo francês convocou o seu embaixador, na Itália, depois do que chamou de "ataques infundados e sem precedentes", de líderes políticos italianos, nos últimos meses e, exortou a Itália a retomar uma postura mais amistosa, com relação à França.

- 14 - Semana: de 16 a 22 de fevereiro de 2019. Milhares de manifestantes de "Coletes Amarelos" fizeram nova marcha, em Paris, neste sábado (16), marcando o 14음 fim de semana de manifestações, na capital francesa, que se transformaram em protestos contra o Governo do Presidente francês, Macron. Os "Coletes Amarelos" reuniram-se no simbólico ponto de 
encontro do Arco do Triunfo, onde os protestos, às vezes, se tornam violentos, antes de marcharem em direção à Torre Eiffel, pelas ruas de Paris. No domingo, o movimento completou três meses e, neste sábado, há concentrações em, pelo menos, 20 cidades do país. Em Paris, foram lançadas várias convocações, em diferentes pontos, com mensagens variadas. Para o domingo, também, há outra convocação, neste caso, declarada e de vontade "pacífica". Uma pesquisa do respeitado Instituto Elabe, publicada na noite de quarta-feira (13), mostrou que $56 \%$ dos franceses acreditam que o movimento deve cancelar os protestos semanais, um aumento de 11 pontos, em relação ao mês anterior. É a primeira vez que eles foram majoritários. Para 64\%, as manifestações se afastaram das reivindicações iniciais. Todavia, os manifestantes disseram que não desistirão, até que, medidas sobre o poder de compra e a democracia inclusiva sejam implementadas. Um dos aspectos que favoreceu o aumento dos que se opõem aos "Coletes Amarelos" são os atos de violência que, segundo contou na terçafeira (12) - o Primeiro Ministro - já se traduziram em 1.796 penas. Em três meses, a polícia francesa realizou 7,5 mil detenções, em concentrações que estão tendo impacto econômico, sobretudo, no comércio e no turismo. No último trimestre de 2018, a França desacelerou seu crescimento econômico e reduziu em 0,1 (um décimo) o seu Produto Interno Bruto (PIB), coincidindo com a crise dos "Coletes Amarelos". Segundo os números do Ministério do Interior, os protestos nas últimas semanas estão muito longe das cerca de 290 mil pessoas que se manifestaram na primeira promoção do movimento, em todo o país, mas, foram perdendo força em termos de mobilização. De acordo com o Ministério, no último dia 09, saíram às ruas 51,4 mil manifestantes, frente aos 84 mil, de 12 de janeiro de 2019. No entanto, os "Coletes Amarelos" rejeitam esses dados e, afirmam que, no sábado passado, foram 118,2 mil, os presentes nos protestos. Segundo dados do Observatório Nacional de Delinquência e Respostas Penais (ONDRP), publicados na quinta-feira (14), 110 carros foram queimados por dia, na França. O fenômeno que se intensificou com o movimento dos "Coletes Amarelos", nos últimos três meses, atingiu, principalmente, o norte e o sudeste da França. Em 2017, 41.200 carros foram incendiados e indenizados pelos seguros. As ocorrências representam uma alta de $2 \%$, em relação ao ano anterior. Os incêndios provocaram a destruição total de $77 \%$ dos carros. Os bombeiros tiveram que fazer, em média, 12,8 intervenções para cada 10 mil veículos. 0 fenômeno não é recente, mas, vem crescendo a cada ano. 0 movimento dos "Coletes Amarelos", iniciado em novembro do ano passado, influenciou o balanço de 2018, ainda não divulgado e, já pesando, no saldo de 2019. A delinquência explodiu, nos últimos 3 meses, afirmou o documento. De novembro de 2018 a janeiro de 2019, os incêndios voluntários de bens públicos, incluindo veículos, tiveram uma alta de $45,2 \%$. As cenas de carros, principalmente, de polícia e de marcas de luxo, pegando fogo, se multiplicaram nas ruas das cidades francesas, durante os protestos. As Associações de 
Prefeitos calculam que as destruições provocadas pelo movimento dos "Coletes Amarelos" somam prejuízos de 20 a 625 milhões de euros, somente, nas 20 maiores cidades francesas.

- 15a Semana: de 23 de fevereiro a 01 de março de 2019. Os manifestantes correm em meio à fumaça, durante uma manifestação antigovernamental, convocada pelo movimento dos "Coletes Amarelos", em Clermont-Ferrand, em 23 de fevereiro de 2019. Os manifestantes saíram às ruas pelo 15ำ sábado consecutivo. Os "Coletes Amarelos" franceses que estão protestando, há mais de 3 meses, contra a política social e fiscal do Presidente Macron. "Não estamos cansados, o movimento não vai acabar e, acho que pode durar mais", assegurou um operário de 22 anos. A manifestação deste sábado, partiu da Av. dos Campos Elíseos e reuniu cerca de 4 mil pessoas. Em toda a França, a manifestação contou com 11 mil e seiscentos "Coletes Amarelos", segundo dados do Ministério do Interior. Em sua primeira manifestação, 282 mil "Coletes Amarelos" lançaram, em todo o país, esse movimento de protesto atípico, apolítico e independente dos sindicatos, originalmente contrário ao aumento do consumo de combustível e exigindo maior poder aquisitivo para os franceses.

- 16 a Semana: de 02 a 08 de março de 2019. Milhares de pessoas vestidas de "Coletes Amarelos" voltaram a protestar neste sábado, pelo 16을 final de semana consecutivo, em Paris e, em outras cidades, para mostrar que eles estão insatisfeitos com as políticas econômicas do Governo que, segundo os manifestantes, tem favorecido as pessoas mais ricas. Em Paris, mais de 1.000 manifestantes marcharam, pacificamente, pelos bairros ocidentais da capital, a partir do Arco do Triunfo. 0 protesto foi realizado sob forte esquema de segurança, após tumultos nas manifestações anteriores. Muitos outros protestos foram organizados em todo o país. Algumas brigas entre manifestantes e policiais ocorreram nas cidades de Lyon, Lille e Nantes, mas, nenhum ferimento grave foi relatado. Os organizadores disseram que querem manter a pressão sobre o Governo, em meio a um "grande debate" de dois meses, iniciado pelo Presidente Macron, para deixar os franceses expressarem seus pontos de vista sobre as questões econômicas e democráticas do país, que terminará neste mês. "Vamos continuar protestando todos os sábados porque Macron não responde nada às exigências dos 'Coletes Amarelos'. Queremos reconstruir nossa democracia e mudar o sistema político de hoje", disse a coordenadora do protesto, em Paris. "Macron é desdenhoso e, nem sequer tenta entender que há pessoas que vivem em grande pobreza e precariedade e, que há muita desigualdade", acrescentou. Os protestos começaram em novembro de 2018, para se oporem aos aumentos de impostos, mas, expandiram-se em uma rejeição pública mais ampla das políticas econômicas de Macron, que manifestantes dizem que favorecem grandes empresas e os ricos sobre os trabalhadores comuns. Macron, desde então, anunciou um pacote de medidas, no 
valor de cerca de 10 milhões de euros, para impulsionar o poder de compra dos trabalhadores e aposentados.

- 17a Semana: de 09 a 15 de março de 2019. Milhares de manifestantes de "Coletes Amarelos" protestaram pelo 17으 fim de semana consecutivo, na França. 0 protesto, em Paris, começou com um tom festivo e, predominantemente, feminino. Algumas mulheres carregavam balões rosa e lideravam uma marcha tranquila, que pedia direitos iguais e igualdade salarial. No final, porém, a polícia disparou gás lacrimogêneo e, usou jatos de água, para dispersar o ato na Av. dos Campos Elíseos. No local, um grupo de manifestantes, com os rostos cobertos por camisas pretas, se recusou a encerrar o protesto. Ainda assim, o clima geral era mais tranquilo, do que o da semana anterior, quando houve queima de carros e quebra-quebra de lojas. 0 Ministério do Interior informou à BFM TV, que havia 7 mil pessoas nas ruas de Paris, neste sábado (09), maior do que os 5,6 mil da semana anterior. Houve protestos, ainda, em Bordeaux, Lille e Le Puy-en-Velay. Os protestos dos "Coletes Amarelos" começaram em novembro de 2018, com o intuito de se oporem aos planos do Presidente Macron, de aumentar impostos. Eles, rapidamente, se transformaram em um amplo movimento com um roll de exigências, incluindo a remoção de Macron do cargo, o restabelecimento do imposto sobre a riqueza, na França e o aumento do poder de compra da classe trabalhadora. 0 movimento atraiu muitos de seus apoiadores dos extremos da política francesa e, de um crescente segmento do eleitorado francês, que se desencantou, completamente, com a política.

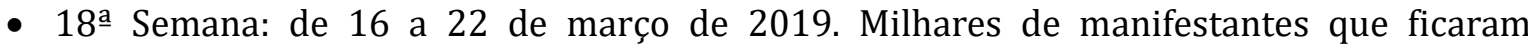
conhecidos como os "Coletes Amarelos", tomaram, novamente, as ruas de Paris, neste sábado e, entraram em confronto com a polícia. Saques, incêndios e barricadas foram registrados na 18 ${ }^{\text {a }}$ semana consecutiva de protestos contra as políticas do Presidente francês, Macron e seu estilo de governar. Os manifestantes afirmaram que as políticas do Palácio do Eliseu trazem um alto custo de vida e, criticam as reformas fiscais, fundamentais, segundo o Governo, para trazer mais justiça social e econômica. Até o fim da tarde, no horário local, a polícia havia detido cerca de 240 pessoas. As manifestações reuniram 14 mil pessoas em todo o país, sendo 10 mil, somente, em Paris, comparadas às 2.800 da semana anterior, de acordo com o Ministério do Interior. As autoridades acreditam que cerca de 1.500 eram "ultraviolentos". Nas redes sociais, alguns organizadores haviam dito que desejavam que a manifestação deste sábado servisse como "um ultimato" ao Governo e aos poderosos. Desde cedo, vários espaços da capital francesa ganharam ares de praça de guerra, com enfrentamentos diretos entre policiais e manifestantes. Ruas ficaram tomadas por barricadas e fumaça, enquanto as Forças 
de Segurança respondiam, com jatos de água e gás lacrimogêneo, para dispersar o grupo, após semanas de relativa calma, durante as marchas e, um número cada vez menor, de participantes. Relatos dão conta de depredações e saques em lojas e agências bancárias, localizadas na tradicional Av. dos Campos Elíseos. Vitrines de várias lojas foram quebradas e, uma filial do Banco Tarneaud foi incendiada, tendo, este incêndio sido combatido pelos bombeiros, que resgataram duas pessoas do prédio. Onze pessoas tiveram ferimentos leves. Bancas de jornais também foram incendiadas, enquanto fogueiras queimavam nas ruas. Quarenta e dois manifestantes ficaram feridos, além de 17 policiais e um bombeiro. Os manifestantes, também, incendiaram uma loja de bolsas e duas bancas de jornais. Os manifestantes também saquearam o histórico e sofisticado restaurante Fouquet's. Eles, ainda, queimaram os toldos do estabelecimento, conhecido em toda a França, por ter sido o local onde o ex-presidente conservador, Nicolas Sarkozy foi comemorar a vitória nas eleições de 2007. Um carro da polícia, também, foi queimado. O Presidente Macron interrompeu a sua viagem a uma estação de esqui, nos Altos Pirineus e, voltou à Paris, devido à violência. Autoridades francesas já esperavam uma grande mobilização neste sábado. Havia, inclusive, expectativa de que ativistas ultraviolentos, alguns vindos do exterior, estariam infiltrados entre os manifestantes. Há algumas centenas de metros da confusão, o Primeiro Ministro classificou a violência como "inaceitável", prometendo levar os responsáveis à justiça. Estamos lidando com centenas e, alguns casos, milhares de pessoas muito determinadas, que estão aqui para criar desordem - afirmou. Pelo menos, 5 mil policiais e seis carros blindados foram mobilizados para fazer a segurança em Paris e cidades como Bordeaux, Dijon, Caen e Montpellier. Segundo as autoridades francesas, outras cerca de 36 mil pessoas participaram de uma não relacionada e pacífica marcha, pedindo ação contra as mudanças climáticas. Os seguidos protestos levaram Macron a fazer maratonas de debates com prefeitos e estudantes em discursos de tom conciliador, numa tentativa de se desvencilhar da imagem arrogante de "Presidente dos Ricos", impingida desde seus primeiros meses no poder. Além disso, ele multiplicou encontros com lideranças partidárias e da sociedade civil. Alterações foram promovidas em sua equipe, no Palácio do Eliseu: colaboradores de longa data deram lugar a outros nomes para criar uma nova dinâmica na Presidência. Antes, um rigoroso crítico dos frequentes encontros de seu antecessor, François Hollande, com jornalistas, Macron mudou de ideia: recentemente, convidou 6 representantes da mídia para uma conversa de 2 horas e meia, em seu gabinete. Em seu forçado processo de mutação, chegou mesmo a ensaiar um mea culpa por suas constantes frases de efeito, percebidas como um desprezo pela população, que tanto prejudicaram sua imagem. Os protestos dos "Coletes Amarelos" começaram devido a alta dos impostos sobre combustíveis. Desde então, eles se ampliaram em uma revolta contra o Presidente Macron e uma classe política vista como fora de contato com as pessoas 
comuns. Os protestos, muitas vezes, se tornaram violentos, causando danos a alguns dos monumentos mais famosos de Paris, como o Arco do Triunfo, em dezembro. Os críticos, também, acusam a polícia de usar força desproporcional na repressão. 0 número de manifestantes que vai às ruas francesas vinha diminuindo, gradualmente, mas, dezenas de milhares de pessoas, ainda, se apresentam, semanalmente, para protestar em toda a França.

- 19a Semana: de 23 a 29 de março de 2019. A polícia disparou gás lacrimogêneo contra manifestantes, em Paris e, confrontos ocorreram em outras cidades francesas, neste sábado, durante o 19 fim de semana consecutivo de protestos dos "Coletes Amarelos", contra o Governo do Presidente Macron. No entanto, com unidades militares instaladas em Paris, pela primeira vez, para apoiar a polícia, a agitação não coincidiu com a escala do último sábado, quando lojas, ao longo da Av. dos Campos Elíseos, foram saqueadas e vandalizadas. A manifestação na capital foi, em grande parte, pacífica, mas, no final da tarde, a polícia disparou gás lacrimogêneo contra manifestantes perto do Boulevard Strasbourg. Alguns manifestantes atearam fogo à caixas. Os confrontos, também, ocorreram em cidades como Lille, no norte da França, Lyon, Nantes, Toulouse, Montpellier e Nice. Os protestos dos "Coletes Amarelos", batizados em homenagem às jaquetas brilhantes que os motoristas franceses têm que manter em seus carros e, que foram usados pelos manifestantes, começaram em 2018, depois que a raiva pública contra o aumento do imposto sobre combustíveis, teve lugar. 0 movimento se transformou em uma reação mais ampla contra o Governo de Macron, apesar da suspensão das taxas de combustível e, muitas vezes, foi marcado por violentos confrontos e saques. Os protestos atingiram a economia francesa com o país reduzindo sua previsão de crescimento econômico para 2019 de 1,7\% para 1,4\%. Os manifestantes foram banidos da Av. dos Campos Elíseos, neste sábado e, o Ministro do Interior da França, disse que as autoridades manejaram bem os últimos protestos, apesar das dificuldades apresentadas pela multidão. Os métodos corretos foram aplicados e os resultados estão lá para serem vistos. A polícia confiscou itens como tacos de baseball e máscaras de possíveis causadores de problemas e, cerca de 170 pessoas foram presas e colocadas sob custódia, no sábado. Mesmo tendo sido banidos dos Campos Elíseos, os manifestantes se reuniram em outros lugares para marchar do sul de Paris, de onde atravessaram o Rio Sena e acabaram na igreja de Sacre Coeur, no norte.

- 20 - Semana: de 30 de março de 2019 a 05 de abril de 2019. Os "Coletes Amarelos" voltaram às ruas, na França, neste sábado (30), na $20^{\circ}$ semana de mobilização, apesar da proibição de alguns locais que foram barrados para manifestações, tendo em vista o medo de novos confrontos. Após os distúrbios e vandalismos na Av. dos Campos Elíseos, em Paris, a 
polícia da capital francesa voltou a banir os protestos na famosa Avenida, bem como, num perímetro incluindo o Palácio do Eliseu e a Assembleia Nacional. Duas manifestações e quatro aglomerações foram declaradas, segundo a polícia, em um comunicado, sem especificar os locais. Ao meio dia, cerca de 300 manifestantes estavam reunidos em frente à Gare de l'Est, em Paris. "Nós viemos pelas mesmas razões que nos motivaram em novembro de 2018. Nós não conseguimos nada desde então", disse à AFP Nadine, que trabalha em Drancy (região de Paris). "Macron, idiota, vamos pegá-lo em casa", cantavam dezenas de "Coletes Amarelos". Muitos colaram seu título de eleitor rasgado, em seus coletes, poucas semanas antes das eleições europeias de maio. Os manifestantes seguiram, então, em direção à Praça do Trocadero. 0 movimento dos "Coletes Amarelos", apolítico, nascido nas redes sociais, questionou a política fiscal e social de Macron, desde meados de novembro de 2018. Esta manifestação relativa a $20^{\text {a }}$ semana, deve ver um novo aumento no número de manifestantes, nas regiões francesas, segundo estimou uma fonte policial. Diante do grande aparato policial implementado em Paris, as autoridades temem uma deslocalização dos confrontos para as cidades do interior. Em Bordeaux, um dos redutos deste movimento social, sem precedentes e, onde o centro da cidade foi, como há várias semanas, proibido aos "Coletes Amarelos", o novo prefeito decretou um dia de "cidade morta", dizendo que está "muito preocupado com o que poderia acontecer". A prefeitura mencionou a presença anunciada de centenas de "black blocs". Em Avingnon, a prefeitura temendo a presença de "grupos militantes violentos", proibiu qualquer manifestação ou reunião, das 8 às 23 horas GMT, dentro da cidade e, em vários eixos periféricos. Em Saint-Etienne, Toulouse, Epinale e Rouen, as prefeituras também proibiram manifestações para evitar a violência e o vandalismo. Em Lille, a prefeitura "proibiu" manifestações e comícios em "algumas ruas do centro", permitindo, no entanto, "rota alternativa". No último sábado, 40.500 pessoas haviam se manifestado na França, incluindo 5.000 em Paris, segundo os números do Ministério do Interior, contestados pelos “Coletes Amarelos", que contabilizaram 127.212 manifestantes em todo o país.

Finalmente, constatamos que o movimento social dos "Coletes Amarelos" deu-se através da trocas de ideias realizadas pelos trabalhadores franceses, por meio das redes sociais, porquanto, foi através das referidas que a nação francesa entrou em entendimento e, posteriormente, saíram às ruas das diferentes cidades francesas, com o propósito de reivindicar o que se lhes afigurou de maior importância para as suas necessidades econômicas e sociais mais urgentes.

\section{AS VIOLÊNCIAS POLICIAL E JURÍDICA NA FRANÇA, CONTRA OS “COLETES AMARELOS”}


O uso da força não pode reprimir iniciativas individuais, exceto em casos de legítima defesa e, deve responder a princípios de absoluta necessidade e gradação, assim como de reversibilidade. A intervenção de unidades não especializadas, em particular empresas de segurança e intervenção e, as brigadas anticriminalidade mobilizadas como reforço, colocam em cheque esse esquema. Geralmente, sem formação em referência à doutrina e aos princípios de manutenção da ordem, essas forças buscam interpelar e se comportam pelo contato, em vez de seguir os princípios de controle e distância.

Tal transformação decorre de uma decisão política. Nessas condições, o ferimento em um pé, assim como outras centenas de ferimentos graves e, mutilações, em particular, nos olhos e nas mãos, registradas desde o início do movimento dos "Coletes Amarelos", não pode ser considerado acidente de autodefesa.

A Inspeção Geral da Polícia e das Forças Armadas lembrava que a França era - e permanece o único país europeu a utilizar munições explosivas em operações de manutenção da ordem, notadamente, as granadas de gás lacrimogêneo do tipo GLLI - F4: os dispositivos que causam lesões por ondas expansivas, produzidos com substância explosiva ou deflagrante, são susceptíveis de mutilar e de ferir moralmente um indivíduo, enquanto aquelas de efeito sonoro intenso podem provocar lesões irreversíveis ao ouvido.

Como se trata de um dispositivo pirotécnico, investidas na cabeça ou no tecido facial, não podem ser, totalmente, excluídas. O Estado, portanto, incorre nesses riscos aos manifestantes com todo conhecimento de causa. No fim de novembro e, início de dezembro de 2018, diversos advogados, entre eles, um autor consagrado, escreveu ao Primeiro Ministro francês, pedindo que essas granadas fossem banidas. Ainda aguardam uma resposta.

Utilizado milhares de vezes, desde meados de novembro, contra manifestantes, "o lançador de balas de defesa" (LBD), carrega um nome, no mínimo, eufemístico. Em 05 de julho de 2018, a Corte Administrativa de Nantes considerou o emprego dessa arma perigoso, durante uma manifestação em 2017: um garoto de 16 anos que, simplesmente, estava próximo ao lançador de projéteis, foi atingido e, o Estado, foi responsabilizado e condenado a pagar uma graúda indenização.

Desde dezembro de 2017, o defensor julgava as características e condições do emprego do LBD inadaptadas à utilização em operações de manutenção da ordem. E, concluía que, o artefato deve ser retirado do armamento das Forças de Segurança, no âmbito de operações de manutenção da ordem. Esse alerta foi, novamente, enviado em janeiro de 2019.

0 apelo teria sido inútil, mesmo se aceito: em 2017, o chefe de polícia de Paris, havia afirmado à Toubon que havia decidido proibir o uso do LBD, nas operações de manutenção da ordem, por sua periculosidade e seu caráter inadequado para esse tipo de contexto - decisão sem nenhuma consequência prática.

Essas armas, assim como o comportamento, às vezes, inapropriado das Forças da Ordem, provocaram centenas de ferimentos nos "Coletes Amarelos". O caráter excepcional desse balanço, 
suscitou a cólera de vários manifestantes que, com frequência, saiam às ruas, pela primeira vez na vida. Podemos perguntar se a obstinação do Governo em utilizar armas e técnicas que podem matar ou mutilar, não se trata de uma estratégia deliberada para dissuadir cidadãos de se manifestarem.

Portanto, desde 2016, os Procuradores da República perseguem manifestantes sem que tenham cometido nenhum ato de violência ou degradação. Com o movimento dos "Coletes Amarelos", em particular, no dia 08 de dezembro, o uso desse delito de "agrupação" tornou-se industrial, conduzindo a um número jamais observado de interpretações e detenções preventivas.

No fim de novembro, em uma circular especial sobre os "Coletes Amarelos", o Ministro da Justiça convidou os magistrados a autorizar policiais a controlar e revistar qualquer indivíduo nos sábados de manifestação em Paris, em outras grandes cidades e nos eixos que conduzem a elas. 0 caráter arbitrário da imensa maioria dessas privações de liberdade aparece na comparação entre o número de interpretações e o número de condenações. Das 1.082 pessoas interpeladas na capital, no dia 08 de dezembro, a grande maioria foi colocada em liberdade, sem desdobramentos jurídicos. Esses procedimentos abusivos não tinham outro objetivo, além de impedir que os "Coletes Amarelos" exercessem seu direito de se manifestar.

Dois dias depois, em 10 de dezembro, uma pessoa chega atordoada à audiência do Tribunal de Paris. Depois de 48 horas de detenção, foi julgada - sozinha - pelo famoso delito de "participação de um grupo, com objetivo de cometer violências ou degradações". Vindo da Bretanha, com 4 (quatro) amigos, esse ex-trabalhador da indústria suína, está parado desde um grave acidente ocorrido na fábrica, em fevereiro de 2016. Para ele, assim como os outros, o movimento dos "Coletes Amarelos" é uma forma de clamar, coletiva e politicamente, sua cólera. Interpelado com seus amigos, no dia 08 de dezembro, em um estacionamento longe do oeste parisiense, onde se desenrolaria a manifestação, foi encontrado com material de proteção e, em seu carro, um cassetete. Todos os 5 (cinco) passaram o fim de semana detidos.

Enquanto os 4 (quatro) amigos foram colocados em liberdade, sem nenhuma consequência jurídica, ele compareceu, sozinho e, foi condenado em primeira instância a 6 (seis) meses de prisão, apesar do delito de agrupamento ser uma intenção coletiva. Decidiu não apelar para não passar, outra vez, pela experiência traumatizante de comparecer diante de juízes.

Se, por um lado, não foi proibido de se manifestar, por outro, se recusa a participar das manifestações com medo de ser pego novamente. Atualmente, frequenta, esporadicamente, as concentrações perto da sua residência.

Ainda é cedo para analisarmos as estatísticas de condenações dos "Coletes Amarelos". Entretanto, há indícios de que as penas pronunciadas em Paris sejam, cada vez mais, duras. Os juízes não hesitam em pronunciar condenações de prisão em regime fechado e, de forma quase sistemática, proibições de entrada na capital, por vários anos, aos interpelados de outras regiões do país. 
Ao desequilíbrio social - magistrados julgando trabalhadores, empregados e desempregados - soma-se a segregação geográfica. Assim, não é raro escutar em uma audiência, um Procurador criticar os "Coletes Amarelos" por saírem de suas regiões para se manifestar. Essa violência simbólica lhes nega, implicitamente, o direito de ir até à capital, para participar das manifestações.

Essas condenações, obtidas graças ao uso extensivo do delito de agrupamento, em detrimento do princípio de interpretação na forma estrita, como figura do Direito Penal, desempenha, de fato, um papel de manutenção da ordem. Elas se apoiam na violência policial para acabar com a mobilização e impedir o exercício de direitos fundamentais. Porém, se a polícia e os tribunais imprimem medo, seus abusos reforçam, também, a raiva e a determinação desses neo-manifestantes.

\section{CONSIDERAÇÕES FINAIS}

Pelo que anteriormente foi analisado, em relação ao movimento social dos "Coletes Amarelos", consideramos que, quanto à sua natureza é, sem dúvida, um movimento que comporta várias faces e, consequentemente, apresenta um conjunto geral complexo.

Em conformidade com o que provocou o advento das manifestações dos "Coletes Amarelos", entre elas, destacamos as seguintes: solicitação nas reduções dos impostos sobre combustíveis, a reintrodução do imposto sobre fortunas, o aumento do salário mínimo, assim como, políticas de melhoria da democracia representativa, mais precisamente, o Referendo de Iniciativa Cidadã, além do impeachment do Presidente francês, Emmanuel Macron.

A partir do processo reivindicatório, observamos o caráter complexo deste movimento social. Assim sendo, analisando-se o movimento e as ações concretas dos "Coletes Amarelos", no decurso de 20 fins de semana, constatamos que constituem um movimento de classe que são movimentos ligados às diferentes classes sociais e, buscam alguma mudança na ordem social existente, principalmente, em relação à diminuição das desigualdades sociais. As manifestações dos "Coletes Amarelos", também, registram um movimento político que tem como principal objetivo, chamar a atenção da população para a importância da participação na vida política e nas decisões do país. Ainda, o referido movimento contempla, também, reivindicações que buscam soluções para situações mais urgentes e que usam a pressão contra o Estado para conseguir as mudanças pretendidas.

Devemos lembrar que o movimento, em questão, não se restringiu, apenas, à capital francesa, Paris, mas, estendeu-se por outras regiões do território francês, incluindo várias cidades, onde constatamos um ritmo significativo do movimento em tela, ao longo de 20 fins de semana.

As principais cidades envolvidas com os protestos dos "Coletes Amarelos" foram as seguintes: Caen, Rouen, Bordeaux, Marselha, Montpeller, Clermont-Ferrant, Renne, Nantes, Toulouse, entre outras. 
Convém que ressaltemos que, a violência visualizada no decurso das manifestações, foram constatadas, tanto da parte dos manifestantes, quanto na atuação dos policiais. Assim, os manifestantes implementaram incêndios, acenderam fogueiras no meio das ruas, saquearam lojas, além de outros estabelecimentos comerciais, depredaram instituições públicas e privadas, danificaram, inclusive, o patrimônio histórico-cultural, do qual a nação francesa será eternamente lembrada e bloquearam estradas, em várias regiões da França. Além disso, ocorreram muitas detenções de "Coletes Amarelos", as quais, à luz das leis francesas, não tiveram muito respaldo legal. Os comentários a respeito da atuação da esfera jurídica francesa causaram preocupação entre muitos juristas, além de outras pessoas entendidas nos dispositivos legais franceses e internacionais.

Os direitos humanos foram flagrantemente atingidos, sendo os grandes prejudicados, exatamente, os manifestantes, isto é, os "Coletes Amarelos".

Por outro lado, os policiais também atuaram com violência, mediante a utilização de bombas de gás lacrimogênio, fortes jatos d'água, além da utilização de balas de borracha, de grande velocidade, rumo às vítimas. Tais instrumentos repressivos causaram ferimentos nos manifestantes, salientandose que os olhos, as mãos, além de ferimentos em outros lugares do corpo, foram identificadas. Ocorreram, ainda, cerca de 10 mortes, ao longo das primeiras 20 semanas em que ocorreram as manifestações. Essas mortes foram observadas, principalmente, nos bloqueios de estradas, com atropelamentos que acarretaram as referidas mortes.

Em face destes acontecimentos, vários segmentos do povo francês começaram a ponderar a respeito da necessidade do término das manifestações, intensões estas que, até agora, não se consumaram, porquanto, os "Coletes Amarelos" seguem em frente nas suas reivindicações.

O Presidente francês Macron, no decurso dos referidos distúrbios populares, acenou com algumas medidas, com o visível propósito de atenuar o clamor da população francesa. Entretanto, apesar de tais providências, os "Coletes Amarelos", ao que tudo indica, desejam modificações que não são referentes à conjuntura, mas, dizem respeito à estrutura, bem como a política da chamada democracia francesa.

Não resta dúvida, que mudanças de estrutura não podem ser feitas, em curto lapso de tempo e, requerem, para sua consecução, um elenco significativo de medidas que, não teríamos certeza se a burguesia que se encontra no poder, atualmente, na França, estaria disposta a conceder, porquanto se fizesse tais concessões, sairia prejudicada no que diz respeito aos seus interesses neoliberais.

Finalmente, ao nosso ver, trata-se de um problema de difícil equacionamento, porquanto, estamos vivendo um período da história da humanidade, no qual só constatamos polarizações das ideias, no decurso dos debates.

Infelizmente, no mundo contemporâneo, as pessoas não estão debatendo as ideias que nos propiciariam uma nova etapa, na história humana, mas, o que é mais visível, são agressões verbais e ameaças contra a integridade física dos portadores das diferentes ideias e posições. 
Enfim, devemos deixar claro o nosso aval ao movimento social dos "Coletes Amarelos", tendo em vista que achamos justas as suas reivindicações, tais como: reduções nos impostos sobre combustíveis, reintrodução do imposto sobre fortunas, aumento do salário mínimo, assim como, políticas de melhoria da democracia representativa, mais precisamente, o Referendo de Iniciativa Cidadã, além do impeachment do Presidente francês, Emmanuel Macron.

Sem dúvida, à luz dos direitos humanos, faz muito sentido os conteúdos reivindicatórios que levaram os "Coletes Amarelos" às ruas de várias cidades do seu país, porquanto, a situação econômica pela qual estão passando não lhe é fácil, deixando-os, na metade do mês, praticamente sem recursos financeiros que asseverem a sua sobrevivência.

\section{REFERÊNCIAS}

BAVA, S. C. Roteiro da Resistência. Le Monde Diplomatique Brasil. Editorial. Ano 12 - Número 139. Fevereiro de 2019. São Paulo. p. 2, 2019.

HALIMI, S.; RIMBERT, P. Luta de Classes na França. Le Monde Diplomatique Brasil. Ano 12 - Número 139. Fevereiro de 2019. São Paulo. p. 3-5, 2019.

KEMPF, R. Das Violências Policiais às Violências Judiciárias. Le Monde Diplomatique Brasil. Ano 12 - Número 139. Fevereiro de 2019. São Paulo. p. 67, 2019.

PINÇON, M. PINÇON-CHARLOT, M. A Casta que Manda na França. Le Monde Diplomatique Brasil. Ano 12 - Número 139. Fevereiro de 2019. São Paulo. p. 8-9, 2019.

PUDAL, B. A Filosofia do Desprezo. Le Monde Diplomatique Brasil. Ano 12 - Número 140. Março de 2019. São Paulo. p. 24-25, 2019.

\section{SITES CONSULTADOS}

'Coletes Amarelos' convocam novos protestos na França (2019). (6 ${ }^{a}$ Semena). Disponível em: < https://jconline.ne10.uol.com.br/canal/politica/na cional/noticia/2018/12/22/coletes-amarelosconvocam-novos-protestos-na-franca-366571.php>. Acesso em: 02/04/2019.

Coletes Amarelos protestam pela sétima semana consecutiva na França. Disponível em: < https://www.trt.net.

tr/portuguese/economia/2018/12/30/coletesamarelos-protestam-pela-setima-semanaconsecutiva-na-franca-1116046>. Acesso em: 02/04/2019.

8a Semana de manifestações dos Coletes Amarelos em França. Disponível em: < http://pt.rfi.fr/franca/2019010 5-8-semana-de-manifestacoes-dos-coletes-amarelosem-franca>. Acesso em: 02/04/2019.

Coletes Amarelos protestam pelo 9으 fim de semana seguido e enfrentam polícia. Disponível em: < https://www.

em.com.br/app/noticia/internacional/2019/01/12/i nterna_internacional,1020862/coletes-amarelosprotestam-pelo-9-fim-de-semana-seguido-eenfrentam-p.shtml>. Acesso em: 03/04/2019.

'Coletes Amarelos' chegam à $10^{\text {a }}$ semana de protestos reunindo $84 \mathrm{mil}$ na França. Disponível em: $<$ https://ww

w1.folha.uol.com.br/mundo/2019/01/coletesamarelos-chegam-a-10a-semana-de-protestosreunindo-84-mil-na-franca.shtml>. Acesso em 03/04/2019.

França: 11ำ protesto dos 'Coletes Amarelos'. Disponível em:

https://anovademocracia.com.br/noticias/1026

10269-franca-11-protesto-dos-coletes-amarelos>. Acesso em: 03/04/2019.

'Coletes Amarelos' voltam às ruas da França em 12ำ fim de semana consecutivo. Disponível em: <https://www.esmael

morais.com.br/2019/02/coletes-amarelos-voltam-as-ruasda-franca-em-12-fim-de-semana-consecutivo/>. Acesso em: 05/02/2019.

'Coletes Amarelos' tomam as ruas da França no 13음 sábado seguido de protestos; Paris tem ferido grave. Disponível em: https://g1.globo.com/mundo/noticia/2019/02/09 /coletes-amarelos-tomam- as-ruas-da-franca -no-13-sabado-seguido-de-protestos.ghtml>. Acesso em: 03/04/2019.

Coletes Amarelos voltam às ruas de Paris no $14^{\circ}$ fim de semana de protestos. Disponível em: < https://g1.globo.com/mundo/noticia/2019/02/16 /coletes-amarelos-voltam-as-ruas-de-paris-no-14o- 
fim-de-semana-de-protestos.ghtml>. Acesso em: 03/04/2019.

'Coletes Amarelos' se manifestam pela $15^{\underline{a}}$ semana consecutiva na França. Disponível em: < https://www.bol.

uol.com.br/noticias/2019/02/23/coletes-amarelosse-manifestam-pela-15-semana-consecutiva-nafranca.html

Acesso em: 26/02/2019.

Franceses protestam pelo $16^{\circ}$ final de semana seguido contra o Governo. Disponível em: < https://www.o povo.com.br/noticias/mundo/2019/03/99812franceses-protestam-pelo-16---final-de-semanaseguido-contra-o-governo.html>. Acesso em: 03/04/2019.

'Coletes Amarelos protestam pelo 17ํㅜ fim de semana consecutivo na França. Disponível em: < https://veja.abril.com.br

/mundo/coletes-amarelos-protestam-pelo-17o-fim-desemana-consecutivo-na-franca/>. Acesso em: 15/03/2019.

França tem 19o sábado consecutivo de protestos dos Coletes Amarelos. Disponível em: $<$ https://oglobo.globo.com/

mundo/franca-tem-19-sabado-consecutivo-de-protestosdos-coletes-amarelos-23546212>. Acesso em: 03/04/2019.
Coletes Amarelos protestam pelo 20ํㅡㅁ final de semana seguido na França. Disponível em: <https://www.correiobrazil

iliense.com.br/app/noticia/mundo/2019/03/30/inte rna_mundo,746388/coletes-amarelos-protestampelo-20-final-de-semana-seguido-na-franca.shtml>. Acesso em: 01/04/2019.

Movimento dos Coletes Amarelos (Da 1a a 5 Semana). Conteúdo aberto. In: Wikipédia: a enciclopédia livre. Disponível em: $<$ https

://pt.wikipedia.org/wiki/Movimento_dos_coletes_am arelos.>. Acesso em: 05/02/2019.

Movimento Social. Conteúdo aberto. In: Wikipédia: a enciclopédia livre. Disponível em: $<$ https://pt.wikipedia.

org/wiki/Movimento_social>. Acesso em: 03/04/2019.

0 que são Movimentos Sociais? Disponível em:< https://www.todapolitica.com/movimentos-sociais/>. Acesso em: 03/04/2019.

Saques, incêndios e confrontos marcam 18aㅗ semana de protestos dos Coletes Amarelos. Disponível em: $<$ http

s://oglobo.globo.com/mundo/saques-incendiosconfrontos-marcam-18-semana-de-protestos-doscoletes-amarelos-23528453>. Acesso em: 20/03/2019. 